\title{
IMPROVING STUDENTS' ABILITY OF FIRST GRADE STUDENTS IN OPERATIONALIZING SUM AND REDUCTION IN MATHEMATICS SUBJECTS BY USING THE ASSISTANCE OF CONGKRIT ITEMS IN SD NEGERI NO. 16 SUNGAI APIT KECAMATAN APIT KABUPATEN SIAK
}

\section{DARMAWATI}

Volume 2 Nomor 1

JIPS ISSN: 2579-5449

\begin{abstract}
Education is the responsibility of the school family and the environment. The success of the three component education is crucial. In addition to these three components, learning methods or strategies, learning tools are also absolutely necessary. The problem of this research is how to use concrete objects can increase the ability of students of Class I in SD Negeri No. 16 Sungai Apit Kecamatan Sungai Siak Kabupaten Siak in operationalizing addition and subtraction in mathematics. This study aims to improve students' ability in operationalizing the addition and subtraction with the help of concrete objects, also expected to benefit students, researchers, and parents. To achieve the purpose of the research, the researcher used classroom action research against the first grade students of SD Negeri 16 Apit Sungai Siak Kecamatan Sungai Apit Kabupaten Siak as many as 37 students who performed in 2 cycles.

The method used in this study is a qualitative approach that describes the actual problems that exist in the field and then reflected

and analyzed based on the theory that support followed by the implementation of research in the field. Data obtained in this study through observation discussion and evaluation.

The results of this study indicate an increase of priminaliry activities, cycle I and cycle II. In priminaliry study, students who experience mastery learning as much as $35 \%$ after the action with the tools of concrete objects. Student learning completeness in the first cycle rose to $97 \%$ followed by the next cycle all students experience complete mastery learning.

The conclusion that can be taken is that concrete objects can help students in operationalizing the addition and reduction of numbers on learning Class I Mathematics, so that learning achievement progress. Other findings children become happy, confident in doing the learning process. Thus it can be suggested that the implementation of education should be environmentally friendly because the environment provides a lot of tools that are cheap, easy to obtain and easily recognized by children.
\end{abstract}

Keywords: addition, subtraction, elementary mathematics, objects of concrete.

\footnotetext{
MENINGKATKAN KEMAMPUAN SISWA KELAS I DALAM MENGOPERASIONALKAN PENUJUMLAHAN DAN PENGURANGAN PADA MATA PELAJARAN MATEMATIKA DENGAN BANTUAN BENDA-BENDA KONGKRIT. DI SD NEGERI NO.16 SUNGAI APIT KECAMATAN SUNGAI APIT KABUPATEN SIAK
} 


\begin{abstract}
ABSTRAK
Pendidikan merupakan tanggung jawab keluarga sekolah dan lingkungan. Keberhasilan pendidikan tiga komponen tersebut sangat menentukan. Disamping tiga komponen tersebut, metode atau strategi pembelajaran, alat-alat pembelajaran juga mutlak diperlukan. Rumusan masalah dalam penelitian ini adalah bagaimana penggunaan benda-benda kongkrit mampu meningkatkan kemampuan siswa Kelas I SD Negeri No.16 Sungai Apit Kecamatan Sungai Apit Kabupaten Siak dalam mengoperasionalkan penjumlahan dan pengurangan pada mata pelajaran Matematika. Penelitian ini bertujuan untuk meningkatkan kemampuan siswa dalam mengoperasionalkan penjumlahan dan pengurangan dengan bantuan benda-benda kongkrit, juga diharapkan bermanfaat bagi siswa, peneliti,maupun orang tua murid. Untuk mencapai tujuan tersebut dilakukan penelitian tindakan kelas terhadap Siswa kelas I SD Negeri No.16 Sungai Apit Kecamatan Sungai Apit Kabupaten Siak sebanyak 37 siswa yang dilakukan dalam 2 siklus.

Metode yang digunakan dalam penelitian ini adalah pendekatan kualitatif yang menggambarkan masalah sebenarnya yang ada

dianalisis berdasarkan teori yang menunjang dilanjutkan dengan pelaksanaan penelitian dilapangan. Data yang diperoleh dalam penelitian ini melalui observasi pengamatan diskusi dan evaluasi.

Hasil penelitian ini menunjukkan peningkatan dari kegiatan pratindakan, siklus I dan siklus II. Dalam penelitian pratindakan siswa yang mengalami ketuntasan belajar sebanyak 35 $\%$ setelah dilakukan tindakan dengan alat bantu benda-benda kongkrit. Ketuntasan belajar siswa dalam siklus I naik menjadi $97 \%$ dilanjutkan siklus selanjutnya seluruh siswa mengalami ketuntasan belajar.

Kesimpulan yang dapat diambil adalah bahwa benda-benda kongkrit dapat membantu siswa dalam mengoperasionalkan penjumlahan dan pengurangan bilangan pada pembelajaran Matematika Kelas I, sehingga prestasi belajar mengalami kemajuan. Temuan yang lain anak menjadi senang, percaya diri dalam melakukan proses pembelajaran. Dengan demikian dapat disarankan bahwa pelaksanaan pendidikan hendaknya berwawasan lingkungan karena lingkungan banyak menyediakan alat bantu yang murah, mudah didapat dan mudah dikenal anak.
\end{abstract} dilapangan kemudian di refleksikan dan

\title{
Kata kunci: penjumlahan, pengurangan, metematika sd, benda kongkrit
}

\section{PENDAHULUAN}

Latar Belakang Masalah, pendidikan merupakan usaha manusia untuk menyiapkan diri dalam perananya dimasa akan datang. Pendidikan dilakukan tanpa ada batasan usia, ruang dan waktu yang tidak dimulai atau diakhiri di sekolah, tetapi diawali dalam keluarga dilanjutkan dalam lingkungan sekolah dan diperkaya oleh lingkungan masyarakat, yang hasilnya digunakan untuk membangun kehidupan pribadi agama, masyarakat, keluarga dan negara. Merupakan suatu kenyataan bahwa pemerintah dalam hal ini diwakili lembaga yang bertanggung jawab didalam pelaksanaan pendidikan di Indonesia, akan tetapi pendidikan menjadi tanggung jawab keluarga, sekolah dan masyarakat yang sering disebut dengan Tri Pusat Pendidikan.

Salah satu keprihatinan yang dilontarkan banyak kalangan adalah mengenai rendahnya mutu pendidikan atau Out Put yang dihasilkan oleh lembaga-lembaga pendidikan formal. Dalam hal ini yang menjadi kambing hitam adalah guru dan lembaga pendidikan tersebut, orang tua tidak memandang aspek keluarga dan kondisi lingkungannya. Pada hal lingkungan keluarga dan masyarakat sekitar sangat menentukan terhadap keberhasilan pendidikan.

Memasuki Tri bulan pertama tahun 2016, ketika diadakan Ulangan Tengah Semester mulai tampak timbul suatu masalah. Sewaktu ulangan jatuh pada mata pelajaran Matematika begitu 
naskah dibagikan, sebagian siswa berteriak-teriak memanggil-manggil ibunya, ada yang garukgaruk kepala, juga tidak sedikit yang menangis karena merasa tidak bisa mengerjakan. Akhirnya nilai yang diperoleh oleh sisa kelas I dalam pelajaran matematika khususnya dalam mengoperasionalkan penjumlahan dan pengurangan. Nilai dari 37 siswa sebagai berikut: (1) 80-100 Amat baik ada 10 siswa $=27 \%$. (2) 55-79 Cukup ada 7 siswa $=10 \%$. (3) $0-54$ Kurang ada 20 siswa $=55 \%$. Dengan kondisi nilai tersebut diatas guru sebagai peneliti merasa pembelajaran matematika dikelas I kurang berhasil.

Selama ini peneliti sudah menggunakan berbagai macam metode untuk mencapai tujuan pendidikan yang diharapkan, tetapi hasilnya masih belum memuaskan. Agaknya memang strategi/pendekatan-pendekatan saja belum cukup untuk menghasilkan perubahan. Meier (2002 : 54) mengatakan bahwa belajar adalah berkreasi bukan mengkonsumsi. Pengetahuan bukanlah suatu yang diserap oleh pembelajaran, melainkan sesuatu yang diciptakan oleh pembelajar.

Pembelajaran terjadi ketika seseorang pembelajar memadukan pengetahuan dan keterampilan baru kedalam struktur dirinya sendiri yang telah ada. Belajar berharfiah adalah menciptakan makna baru, sejauh ini pendidikan kita didominasi oleh pandangan bahwa pengetahuan sebagai perangkat fakta-fakta yang harus dihafal. Kelas masih berfokus pada guru sebagai sumber utama pengetahuan. Kemudian ceramah menjadi pilihan utama strategi belajar. Untuk itu diperlukan strategi belajar baru yang memberdayakan siswa sebuah strategi belajar tidak mengharuskan siswa menghafalkan faktafakta tetapi sebuah strategi yang mendorong siswa mengkonstruksikan pengetahuan dibenak mereka sendiri.

\section{METODE PENELITIAN}

Pendekatan yang digunakan dalam penelitian ini adalah pendekatan Kualitatif yaitu menggambarkan masalah sebenarnya yang ada di lapangan, kemudian direfleksikan dan dianalisis berdasarkan teori menunjang dilanjutkan dengan pelaksanaan tindakan di lapangan. Pendekataan Kualitatif dalam penelitian ini digunakan untuk menelusuri dan mendapatkan gambaran secara
Dalam upaya itu siswa perlu guru sebagai pengarah dan pembimbing. Dalam kelas tugas guru adalah membantu siswa mencapai tujuan. Maksudnya guru lebih banyak berurusan dengan strategi dengan alat bantu yang dikenal siswa disekitarnya, dari pada memberi informasi.memang pendidikan siswa kelas I Sekolah Dasar masih identik dengan dunia bermain, karena siswa kelas I belum dapat melepas keterkaitannya dengan pendidikan Taman Kanak-Kanak sebelumnya, karena itu benda-benda disekitar sekolah sangat membantu proses pembelajaran siswa.

Bertitik tolak dari latar belakang masalah di atas peneliti ingin meningkatkan kemampuan siswa kelas I Sekolah Dasar dalam mengoperasionalkan penjumlahan dan pengurangan pada mata pelajaran Matematika dengan bantuan benda-benda kongkrit.

Berdasarkan latar belakang masalah di atas maka perumusan masalahnya sebagai berikut: Bagaimana penggunaan benda-benda kongkrit mampu meningkatkan kemampuan siswa kelas I SD Negeri No.16 Sungai Apit Kecamatan Sungai Apit Kabupaten Siak dalam mengoperasionalkan penjumlahan dan pengurangan pada mata pelajaran Matematika.

Dengan bantuan benda-benda kongkrit disekitar sekolah siswa kelas I SD Negeri No.16 Sungai Apit Kecamatan Sungai Apit Kabupaten Siak mampu mengoperasionalkan penjumlahan dan pengurangan pada mata pelajaran Matematika.

Berpijak dari permasalahan yang diteliti maka tujuan penelitian ini adalah: Meningkatkan kemampuan belajar siswa dalam mengoperasionalkan penjumlahan dan pengurangan dengan bantuan benda-benda kongkrit.

jelas tentang situasi kelas dan tingkah laku siswa selama proses pembelajaran berlangsung. Penelitian Tindakan Kelas dilaksanakan secara bersiklus. Pembelajaran dilakukan di kelas I SD Negeri No.16 Sungai Apit Kecamatan Sungai Apit Kabupaten Siak.

Jenis penelitian yang digunakan dengan Penelitian Tindakan Kelas (PTK) karena ingin 
menerapkan pembelajaran untuk meningkatkan kemampuan siswa kelas I dalam mengoperasionalkan penjumlahan dan pengurangan bilangan dengan alat bantu bendabenda kongkrit di sekitar sekolah.

Peneliti dibantu 2 Orang pengamat senantiasa hadir dan kehadirannya mutlak diperlukan karena penelitian ini menggunakan pendekatan kualitatif. Kedudukan peneliti dalam penelitian ini adalah sebagai perencana, pelaksana, pengumpul, penganalisa, penafsir data dan akhirnya sebagai pelaporan hasil penelitian.

Ketika pelaksanaan penelitian , kehadiran peneliti di lapangan berperan sebagai peneliti sekaligus pelaksana pembelajaran, pengobservasi dalam rangka pengumpulan data. Penelitian ini dilakukan dalam 2 siklus untuk siklus I dua pertemuan dan siklus II tiga pertemuan. Pada setiap akhir tindakan, peneliti bersama pengamat melakukan refleksi terhadap pelaksanaan tindakan.

Dalam penelitian ini, peneliti bertindak sebagai Guru Matematika kelas I, jadi disamping bekerja mengumpulkan dan menganalisis data di lapangan, peneliti berperan langsung dalam proses pembelajaran dari perencanaan, pelaksanaan pengajaran sampai dengan penilaian.

Lokasi penelitian tindakan kelas ini adalah SD Negeri No.16 Sungai Apit Kecamatan Sungai Apit Kabupaten Siak. SD Negeri No.16 Sungai Apit memiliki 8 kelas masing-masing kelas ratarata terdiri dari 40 siswa, hanya kelas I yang berjumlah 37 siswa. Alasan dipilihnya SD Negeri No.16 Sungai Apit Kecamatan Sungai Apit Kabupaten Siak adalah: (1) SD Negeri No.16 Sungai Apit Kecamatan Sungai Apit Kabupaten Siak merupakan tempat peneliti berdinas. (2) Peneliti sebagai Guru Mata pelajaran Matemetika I (3) Di sekitar sekolah banyak tersedia benda-benda kongkrit yang digunakan sebagai alat pembelajaran. (4) Jumlah siswa kelas I jumlahnya paling sedikit, sehingga harapan peneliti dapat memberikan perhatian yang maksimal pada waktu kegiatan pembelajaran, sehingga pembelajaran berlangsung secara efektif. (5) SD Negeri No.16 Sungai Apit Kecamatan Sungai Apit Kabupaten Siak adalah sekolah desa yang berdekatan dengan komplek Perumahan sehingga memiliki latar belakang kondisi siswa, pendidikan Orang Tua siswa, kondisi sosial ekonomi yang sangat heterogen. (6) Kemampuan akademik siswa kelas I yang beragam ada yang pandai dan cepat tanggap dalam menyelesaikan soal, ada yang sedang dan bahkan ada yang lambat sekali.

Sumber data dalam penelitian ini, barasal siswa kelas I SD Negeri No.16 Sungai Apit Kecamatan Sungai Apit Kabupaten Siak tahun 2016 yang berjumlah 37 siswa terdiri dari 16 siswa laki-laki dan 21 siswa perempuan.

Jenis data yang dihimpun adalah data yang kualitatif, berupa hasil Observasi, diskusi dan penilaian. Observasi dilakukan terhadap kegiatan pembelajaran Matematika tentang operasional penjumlahan dan pengurangan bilangan. Dari hasil Observasi ini peneliti banyak menemukan masalah-masalah pada siswa kelas I diantaranya siswa sebagian besar belum bisa mengoperasionalkan penjumlahan dan pengurangan bilangan. Akhirnya peneliti mencoba untuk mengatasi masalah yang dialami siswa kelas I dalam mengoperasionalkan penjumlahan dan pengurangan bilangan dengan alat bantu benda-benda konkrit di sekitar sekolah. Benda - benda kongkrit di sekitar sekolah yang peneliti gunakan adalah biji kacang , kerikil , buah nyamplung. Sedangkan penilaian dilakukan setiap pada setiap akhir pertemuan dalam pembelajaran yang berfungsi untuk menguji sejauh mana keberhasilan pembelajaran Matematika dengan menggunakan alat bantu benda-benda kongkrit di sekitar sekolah.

Prosedur pengumpulan data dilakukan berdasarkan bentuk data yang diperoleh. Untuk memperoleh data yang diinginkan dalam pembelajaran Matematika khususnya mengopersionalkan penjumlahan dan pengurangan bilangan dilakukan dengan teknik Observasi, diskusi dan evaluasi hasil belajar yang hasilnya akan dilaksanakan dalam bentuk skor. Sebelum dilaksanakan pelaksanaan tindakan kelas peneliti mengidentifikasi masalah pembelajaran Matematika Kelas I dilanjutkan dengan upaya pemecahan masalah yang dihadapi Guru dan siswa.

Diskusi dilaksanakan bersama 2 orang pengamat yang membantu pelaksanaan kegiatan penelitian, pengamat melakukan pencatatan terhadap semua kegiatan siswa, kreatifitas siswa, perhatian siswa terhadap pelajaran, penggunaan alat-alat bantu pembelajaran, kedisiplinan siswa, keberanian siswa dalam menyelesaikan masalah, keberanian dalam mengemukakan pendapat, penilaian terhadap siswa. Dari hasil catatan pengamat ini kemudian didiskusikan bersama peneliti agar dalam kegiatan selanjutnya berjalan lebih efektif. 
Kegiatan penilaian dilakukan dengan penilaian proses dan evaluasi akhir pelajaran. Penilaian proses dilaksanakan pada saat pembelajaran berlangsung dengan menguji siswa maju ke depan kelas untuk menyelesaikan soal . Ketika maju ke depan kelas peneliti memberi kesempatan yang sama antara siswa yang memiliki kemampuan yang lebih dengan siswa yang memiliki kemampuan yang cukup, sedangkan siswa yang memiliki kemampuan lebih lambat dari teman yang lainnya diberi kesempatan yang lebih besar agar siswa tersebut dapat mengejar ketinggalannnya dari siswa yang lain. Kegiatan akhir pembelajaran berupa penilaian yang ditentukan dengan skor dengan tujuan untuk mengukur keberhasilan pembelajaran dalam 1 pertemuan, dari masingmasing pertemuan kemudian diakumulasi kan dalam bentuk tabel untuk mengetahui sejauh mana perkembangan pembelajaran Matematika dalam setiap pertemuan.

Data hasil penelitian yang terkumpul berasal dari data observasi, diskusi dan evaluasi. Tehnik analisis yang digunakan dalam penelitian mengikuti langkah Hopkins (1993:151) dengan tiga tahap analisis yaitu tahap kategorisasi, validasi dan intepretasi data.

Kategorisasi data dilakukan dengan memilih-milih data yang terkumpul berdasarkan kategori tertentu yang di tetapkan. Kategori yang dimaksud meliputi konsepsi awal siswa, jenis pertanyaan siswa, eksplorasi siswa, aktivitas siswa, penilaian akhir siswa.

Validasi merupakan data yang kedua, dalam kegiatan ini dilakukan dengan tujuan untuk mengelola data yang betul-betul objektif, valid dan diakui kebenarannya, validasi data dilakukan dengan observasi lapangan untuk mengetahui masalah-masalah yang terjadi. Melakukan diskusi dengan pengamat tentang hasil-hasil catatan yang ada di lapangan, kemudian diakhiri dengan penilaian baik penilaian proses maupun penilaian akhir kegatan. Dari penilaian akhir kegiatan data yang di peroleh disusun secara sistematis, dibedakan antara penilaian sebelum pelaksanaan penelitian tindakan kelas dengan sesudah dilaksanakan penelitian tindakan kelas, agar dapat digunakan untuk menarik satu kesimpulan, sehingga kesimpulan yang diperoleh benar-benar valid, sahih dan objektif.

Pengecekan Keabsahan Data dilakukan dengan memadukan hasil observasi, hasil-hasil catatan dari pengamat beserta evaluasi yang dilakukan untuk menjaga keabsahan data perlu dilakukan diskusi-diskusi dengan pengamat sehingga kesimpulan yang diperoleh sangat tepat sesuai dengan hasil penelitian.

Penelitian tindakan kelas dilakukan dalam dua siklus. setiap siklus diawali dengan perencanaan penerapan tindakan dan observasi, serta diakhiri dengan refleksi. Tahap-tahap penelitian dirinci sebagai berikut:

Tahap ini dilakukan dengan tujuan untuk meng identifikasi masalah yang dihadapi oleh siswa kelas I yang berkaitan dengan pembelajaran Matematika. Kegiatan tersebut diantaranya : Observasi terhadap pembelajaran Matematika kelas I, buku-buku yang digunakan dan alat-alat bantu pembelajaran yang digunakan. Meneliti siswa-siswa kelas I secara individual dan mencatat semua kesulitankesulitan yang dihadapi oleh siswa. Melakukan diskusi dengan para pengamat kemudian menentukaan alat bantu pembelajaran yang tepat, mudah didapat dan tidak memerlukan beaya yang mahal untuk mendapatkannya. Memilih dan menentukan topik dari pelajaran Matematika kelas I yang akan digunakan untuk Penelitian Tindakan Kelas. Menentukan waktu pelaksanaan Penelitian Tindakan Kelas.

Tindakan Siklus pertama, Perencanaan. Menentukan materi pembelajaran penjumlahan dan pengurangan bilangan dengan hasil kurang dari 20. Menyusun rencana pembelajaran. Menentukan alat bantu yang akan digunakan dalam pembelajaran. Menyusun Lembar Kegiatan Siswa. Melakukan kegiatan pembelajaran dalam siklus I menjadi dua pertemuan. Melakukan Evaluasi siswa.

Tindakan, siswa melakukan kegiatan tentang proses penjumlahan dan pengurangan bilangan dengan alat bantu benda kongkrit. Siswa mengerjakan LKS secara individual. Peneliti melakukan bimbingan dibantu dua orang pengamat. Pengamatan. Aktivitas dan tingkah laku siswa selama proses pembelajaran berlangsung dicatat oleh peneliti dan pengamat sebagai bahan diskusi. Pengamat dan peneliti melakukan diskusi bersama untuk melakukan kegiatan selanjutnya.

Refleksi. Catatan dari pengamat / observer dikaji kembali sebagai bahan perbaikan siklus berikutnya. Mengadakan remidial terhadap siswa yang mengalami keterlambatan belajar. Tindakan Siklus II . Perencanaan. Menentukan rencana pembelajaran untuk siklus II tentang penjumlahan dan pengurangan bilangan pada 
pelajaran matematika. Menyusun rencana pembelajaran. Menentukan alat bantu pembelajaran. Menyusun lembar kegiatan siswa. Melakukan kegiatan pembelajaran untuk siklus II dilakukan dalam 3 pertemuan. Melakukan evaluasi belajar siswa.

Tindakan. Siswa mengerjakan LKS secara individual. Peneliti dibantu pengamat membimbing siswa dalam melakukan pembelajaran. Pengamatan. Melakukan kegiatan pengamatan selama proses pembelajaran berlangsung. Mencatat semua tingkah laku dan kegiatan siswa selama proses pembelajaran berlangsung. Melakukan diskusi bersama peneliti. Refleksi. Melakukan kegiatan remidial terhadap siswa yang mengalami keterlambatan belajar. Proses pembelajaran berlangsung aktif. Hasil catatan pengamat dikaji kembali sebagai acuan tindakan berikutnya.

\section{HASIL PENELITIAN DAN PEMBAHASAN}

Sesuai dengan topik dalam bab ini yaitu paparan data dan temuan-temuan dalam penelitian maka penyajiannya tidak dipisahpisahkan, karena merupakan satu kesatuan. Data yang akan disajikan dipaparkan berdasarkan pelaksanaan penelitian dalam siklus yang akan diperinci per pertemuan. Penelitian Tindakan Kelas ini akan dilaksanakan dari kegiatan Observasi atau pra tindakan kemudian dilanjutkan pada kegiatan tiap pertemuan dalam siklus-siklus yaitu siklus I dan II.

Paparan Data dan Temuan Penelitian pada kegiatan Observasi Pra Tindakan. Kegiatan awal penelitian diawali dengan Observasi pada kelas I SD Negeri No.16 Sungai Apit Kecamatan Sungai Apit Kabupaten Siak pada hari Selasa tanggal 10 Oktober 2016, kebetulan saat itu sedang dilaksanakan Ulangan Tengah Semester I. Pada hari tersebut jam ke I adalah mata pelajaran Matematika. Sebagaimana yang dijelaskan peneliti pada latar belakang dalam penelitian ini bahwa siswa kelas I banyak yang berteriak-teriak memanggil-manggil Ibunya, menangis dan menggaruk-garuk kepala karena mengalami kesulitan dalam mengerjakan soal. Memang bila dilihat dari latar belakang siswa yang masuk ke SD Negeri No.16 Sungai Apit Kecamatan Sungai Apit Kabupaten Siak sangat heterogen, karena heterogenitas latar belakang siswa maka heterogen pula kemampuan dalam pola berfikirnya.

Nilai dari hasil ulangan tersebut kemudian peneliti ambil datanya untuk dianalisis, kesimpulan yang diperoleh yaitu :

Nilai $>75$ sebanyak 13 siswa $=35 \%$ dari keseluruhan siswa.

Nilai $<75$ sebanyak 24 siswa $=65 \%$ dari keseluruhan siswa.

Peneliti mengambil standar nilai 75 terendah, karena nilai 75 diatas dari nilai cukup untuk suatu keberhasilan pembelajaran.Namun karena siswa kelas I SD Negeri No.16 Sungai Apit Kecamatan Sungai Apit Kabupaten Siak nilai > 75 sebanyak $35 \%$ berarti pembelajaran Matematika di kelas I belum berhasil.

Materi pelajaran Matematika kelas I tentang penjumlahan dan pengurangan bilangan berkisar pada deret hitung 1 sampai 20 . Kemudian peneliti bersama rekan-rekan yang lain mencoba memecahkan masalah ini dengan cara memberi soal yang sejenis dengan materi dalam ulangan. Akhirnya ada siswa yang bertanya : Diapakan Pak ini ? Dengan apa Pak ?

Apabila diresapi pertanyaan siswa tersebut dapat ditarik suatu kesimpulan bahwa siswa belum mampu mengoperasionalkan penjumlahan dan pengurangan bilangan tanpa alat bantu pembelajaran.

Berangkat dari hasil Observasi inilah peneliti bersama rekan-rekan Guru berdiskusi bersama dan dicapai suatu kesimpulan bahwa untuk meningkatkan kemampuan siswa dalam mengoperasionalkan penjumlahan dan pengurangan bilangan memerlukan alat bantu pembelajaran. Alat bantu pembelajaran tidak perlu mahal cukup dengan menggunakan bendabenda kongkrit yang ada di sekitar sekolah seperti : kerikil, kelereng, biji-bijian, buah nyamplung.

Sesuai dengan tahap pembelajaran penjumlahan dan pengurangan bilangan dilakukan dalam 2 siklus dengan 5 kali pertemuan 
Siklus I , Perencanaan : Menentukan pokok bahasan dalam siklus I yaitu penjumlahan dan pengurangan bilangan dengan pola mendatar untuk 2 bilangan dengan hasil kurang dari 20 . Menyusun Rencana Pembelajaran. Menetapkan tujuan pembelajaran dalam Siklus I yaitu: Siswa dapat membilang dengan bilangan 1 sampai 20 . Siswa dapat mengoperasionalkan penjumlahan dan pengurangan bilangan dengan pola mendatar untuk dua bilangan dengan alat bantu benda kongkrit disekitar sekolah. Mempersiapkan lembar kegiatan siswa. Mempersiapkan perangkat dan alat bantu pembelajaran, dalam siklus I ini peneliti menggunakan alat bantu benda kongkrit kerikil. Menetapkan subyek penelitian. Subyek penelitian adalah siswa kelas I SD Negeri No.16 Sungai Apit Kecamatan Sungai Apit Kabupaten Siak sebanyak 37 siswa. Waktu penelitian Siklus I. Dalam siklus I penelitian tindakan kelas dilaksanakan dalam 2 pertemauan yaitu : Penelitian I Siklus I Dilaksanakan pada hari sabtu tgl 30 september 2016, jam I dan II dengan alokasi waktu 35 x 2 jam. Pertemuan II Siklus I dilaksanakan pada hari selasa tanggal 3 oktober 2016 jam III dan IV dalam alokasi waktu 35 x 2 Jam. Mempersiapkan alat evaluasi. Mempersiapkan lembar pengantar.

Apersepsi dengan alokasi waktu 10 menit diisi dengan kegiatan : Peneliti masuk kelas dengan 2 orang pengamat tepat pukul 07.00 dilanjutkan dengan ucapan selamat. Peneliti mengajak subyek penelitian untuk berdoa bersama-sama agar memperoleh ilmu yang bermanfaat. Peneliti mengabsen subyek penelitian satu persatu. Peneliti mengulas kembali pelajaran yang lalu dengan mengembangkan pola tanya jawab mengenai penjumlahan dan pengurangan bilangan tanpa menggunakan alat bantu benda kongkrit untuk mengukur sejauh mana penguasaan anak-anak tentang penjumlahan dan pengurangan bilangan. Pelaksanaan Proses Belajar Mengajar dengan alokasi waktu 40 menit. Peneliti mengajak sisa bersama-sama menghitng kerikil yang diberikan oleh peneliti. Peneliti menjelaskan cara mengoperasionalkan penjumlahan dan pengurangan bilangan dengan alat bantu kerikil.

Contoh : $6+4=\ldots$. berarti : Ambil kerikil 6, ambil lagi kerikil 4. Berapa banyak kerikil semuanya? $18-9=\ldots .$. berarti : Sediakan kerikil 18 ambil 9. Berapa sisa kerikil ? Peneliti membimbing siswa bersama-sama tentang penjumlahan dan pengurangan bilangan dengan alat bantu benda kerikil. Beberapa siswa diberi kesempaatan mendemonstrasikan penjumlahan dan pengurangan bilangan dengan alat bantu kerikil didepan kelas diikuti oleh seluruh siswa dalam kelas. Siswa mengerjakan Lembar Kegiatan Siswa secara individual dengan alokasi waktu 20 menit. Peneliti berkeliling dengan dibantu pengamat untuk memberi bimbingan kepada siswa dalam mengerjakan LKS secara individual

Pertemuan II, Apersepsi dengan alokasi waktu 10 menit digunakan untuk : Mengulas materi penjumlahan dan pengurangan bilangan yang dijelaskan waktu yang lalu secara singkat sambil melakukan tanya jawab terhadap siswa. Memberi kesempatan kepada siswa untuk tampil didepan kelas menyelesaikan soal materi yang lalu dengan alat bantu benda kerikil. Pelaksanaan Proses Belajar Mengajar Dengan alokasi waktu selama 40 menit.

Peneliti menjelaskan tentang penjumlahan dan pengurangan bilangan 3 angka dengan hasil kurang dari 20 dengan alat bantu benda kerikil Contoh : $6+4+5=\ldots \ldots$. berarti : Ambil kerikil 6, ambil lagi 4, ambil lagi 5. Berapakah banyak kerikil semuanya ? 19-5-4 $=\ldots . .$. berarti : Sediakan kerikil 19, ambil 5, ambil lagi 4. Berapakah sisa kerikilnya ?

Peneliti mengajak siswa bersama-sama melakukan penjumlahan dan pengurangan 3 angka dengan alat bantu benda kerikil. Peneliti mendemonstrasikan penjumlahan dan pengurangan bilangan 3 angka didepan kelas diikuti seluruh siswa. Siswa diberi kesempatan untuk tampil didepan kelas menyelesaikan soal soal latihan dibawah bimbingan peneliti. Siswa mengerjakan LKS secara individual di bawah bimbingan peneliti dibant pengamat. Peneliti berkeliling untuk mengawasi siswa dalam mengoperasionalkan penjumlahan dan pengurangan bilangan dengan alat bantu benda kerikil.

Evaluasi dengan alokasi waktu 20 menit : Alat evaluasi berupa Lembar soal dengan sistim penilaian betul 1 nilai 1 , salah 1 nilai kurang 1 Banyak soal 10 nomor. Evaluasi dilaksanakan dengan tujuan untuk mengukur keberhasilan selama proses pembelajaran tentang penjumlahan dan pengurangan bilangan dengan alat bantu benda kongkrit kerikil. Hasil evaluasi digunakan sebagai pembanding dengan evaluasi berikutnya untuk mengetahui keberhasilan dan ketuntasan belajar. 
Tindakan siswa melakukan proses penjumlahan dan pengurangan bilangan dengan menggunakan alat bantu benda kongkrit kerikil. Peneliti melakukan bimbingan untuk mengoperasionalkan penjumlahan dan pengurangan bilangan dengan alat bantu benda kongkrit sambil melakukan penilaian proses. Siswa mengerjakan LKS secara individual dengan alat bantu kerikil. Siswa mengerjakan soal evaluasi.

Pengamatan aktivitas dan tingkah laku siswa selama proses belajar mengajar berlangsung oleh peneliti dibant oleh pengamat. Hasil catatan selama melakukan pengamatan digunakan sebagai bahan diskusi

Refleksi, Catatan dari Observer direnungkan dan dikaji kembali untuk bahan perbaikan pada siklus berikutnya. Mengadakan remidial terhadap siswa yang mengalami kesulitan dalam belajar. Semua siswa aktif melakukan pembelajaran Matematika dengan menggunakan alat bantu benda-benda kerikil. Semua siswa mampu mengoperasionalkan penjumlahan dan pengurangan bilangan dengan hasil kurang dari 20 melalui alat bantu benda kongkrit kerikil. Pada siklus berikutnya perlu diadakan penggantian alat bantu, misalnya abakus atau sempoa. Materi pembelajaran ditingkatkan taraf kesulitannya, bila perlu soalsoal cerita disampaikan untuk mengetahui sejauh mana anak memahami bacaan . Nilai yang diperoleh selama evaluasi oleh siswa telah memenuhi standar terrendah $>75$ sebagai tolok ukur ketuntasan belajar.

Pada bab ini akan disajikan pembahasan mengenai paparan data temuan penelitian pada Bab IV sebelumnya. Bila dilihat dari rumusan masalah yang dijelaskan sebelumnya, maka pembahasan dapat diuraikan menjadi dua bagian yaitu:

1.Penggunaan benda-benda kongkrit mampu meningkatkan kemampuan belajar.

Kegiatan pembelajaran dalam upaya untuk meningkatkan kemampuan belajar siswa kelas I SD dalam proses penjumlahan dan pengurangan bilangansangat dibutuhkan metode dan alat bantu yang tepat. Siswa Kelas I tidak akan berhasil dalam pembelajaran apabila hanya menghafal konsep. Perlu diingat bahwa siswa Kelas I masih identik dengan dunia bermain dan sangat mengenal dengan benda-benda lingkungan sekitarnya. Jadi alangkah baiknya bila dalam proses pembelajarannya juga menggunakan alat bantu benda-benda kongkrit disekitar sekolah.
Sebelum penelitian tindakan kelas dilaksanakan peneliti dibantu beberapa guru melakukan Observasi lapangan sebagai tindakan awal. Kegiatan ini dilakuakan untuk mengetahui seberapa besar tingkat ketuntasan belajar siswa dalam melakukan operasi penjumlahan dan pengurangan bilangan dalam pembelajaran Matematika. Dari kegiatan Observasi awal ini diperoleh data ulangan sebagai berikut: 1) Siswa yang memperoleh nilai $>75$ ada 13 siswa kurang lebih $35 \%$. 2) Siswa yang memperoleh nilai $<75$ ada 24 siswa kurang lebih $65 \%$

Dari data tersebut dapat disimpulkan bahwa operasi penjumlahan dan pengurangan bilangan belum berhasil.

Kemudian peneliti mencoba untuk meningkatkan prestasi belajar siswa dalam mengoperasionalkan penjumlahan dan pengurangan bilangan dengan menggunakan alat bantu benda-benda kongkrit di sekitar sekolah setelah dilakukan penelitan tindakan kelas peneliti mengambil evaluasi dari masing-masing silkus dengan tujuan untuk mengetahui ada tidaknya peningkatan prestasi belajar siswa. Berdasarkan hasil evaluasi pembelajaran dalam siklus I dengan standart nilai terrendah 75 , siswa yang memperoleh nilai $>75$ sebanyak 36 siswa atau kurang lebih $97 \%$ sedangkan hasil evaluasi pada siklus II dengan standart nilai yang sama, semua siswa memperoleh nilai $>75$ atau $100 \%$. Dari uraian di atas dapat disimpulkan : 1) Nilai evaluasi Silkus I dan Siklus II mengalami peningkatan. 2) dengan alat bantu benda-benda kongkrit siswa dapat mengoperasionalkan penjumlahan dan pengurangan bilangan. 3) Standart kelulusan belajar tercapai. Siswa mampu mengoperasionalkan penjumlahan dan pengurangan bilangan.

Penggunaan benda-benda kongkrit dalam mengoperasionalkan penjumlahan dan pengurangan bilangan ini dilaksanakan karena siswa atau subyek penelitian belum mampu mengoperasionalkan penjumlahan dan pengurangan tanpa alat bantu. Pada pembelajaran siswa diberi arahan dari instruksi cara menggunakan alat peraga sehingga dapat memperlancar proses pembelajaran. Dengan demikian pembelajaran dengan memanfaatkan alat bantu peraga harus dapat dilakukan oleh subyek penelitian.

Pembelajaran dalam pertemuan I diarahkan pada konsep dasar penggunaan alat benda-benda kongkrit dalam pengoperasian penjumlahan dan pengurangan bilangan dengan 
hasil kurang dari 20 sesuai dengan perkembangan berfikir anak pada pembelajaran pertemuan I subyek penelitian diarahkan untuk aktif menggunakan alat peraga benda-benba kongkrit. Dalam pembelajaran ini diharapkan siswa merasa senang dan tidak merasa takut dalam mengoperasionalkan penjumlahan dan pengurangan bilangan dalam pembelajaran Matematika.

Kegiatan pembelajaran yang berlangsung dalam pertemuan I dan pertemuan selanjutnya terlihat sunyek penelitian nampak memahami konsep penjumlahan dan pengurangan bilangan

\section{KESIMPULAN DAN SARAN}

Kesimpulan dan saran dalam bab ini disajikan berdasarkan temuan dan pembahasan pada bab sebelumnya. Simpulan yang diambil sesuai dengan rumusan masalah yang telah dikemukakan pada bab sebelumya :

Berdasarkan hasil analisis dan pembahasan tentang upaya meningkatkan kemampuan siswa kelas I dalam mengoperasionalkan penjumlahan dan pengurangan bilangan pada pembelajaran Matematika dengan bantuan benda-benda kongkrit dapat disimpulkan sebagai berikut: 1).Siswa yang pada awalnya merasa takut dan bingung dengan pembelajaran Matematika, melalui alat bantu benda-benda kongkrit rasa percaya diri siswa timbul dan merasa senang terhadap pembelajaran Matematika terutama tentang mengoperasionalkan penjumlahan dan pengurangan bilangan.2). Siswa dapat menggunakan benda-benda kongkrit dengan baik dalam mengoperasionalkan penjumlahan dan pengurangan bilangan pada pembelajaran Matematika. 3).Pembelajaran dengan menggunakan alat bantu benda-benda kongkrit di sekitar sekolah dapat meningkatkan kemampuan siswa kelas I dalam mengoperasionalkan penjumlahan dan pengurangan bilangan dengan hasil sampai 20. Hal ini dibuktikan dengan hasil evaluasi siklus I menunjukkan standart ketuntasan belajar mencapai $97 \%$ dan siklus II seluruh siswa mengalami ketuntasan belajar. yang diawali dari penjumlahan dan pengurangan 2 angka sampai 3 angka. Siswa kelas I merupakan pondasi sekolah dasar 6 tahun. Apabila pondasi dibangun dengan baik dan konsep yang benar maka lulusan / Out Put akan berhasil.

Benda-benda kongkrit yang digunakan sebagai alat bantu penjumlahan dan pengurangan bilangan merupakan alat bantu sementara sebagai penanaman konsep belajar. Apabila siswa sudah berhasil menguasai konsep, maka alat bantu berupa benda-benda kongkrit akan dihilangkan.

4).Kegiatan pembelajaran yang dilaksanakan menjadi lebih menarik dan menyenangkan bagi siswa.5).Beban Orang tua siswa menjadi lebih ringan karena benda-benda disekitar sekolah tidak harus dibeli dan mudah mendapatkannya.

Dengan mengacu pada temuan dari penelitian tindakan ini disampaikan beberapa saran penyampaian saran ini merupakan sumbangan pemikiran bagi peneliti untuk memperbaiki dan meningkatkan pembelajaran dikelas I SD, khususnya pembelajaran Matematika saran-saran yang dikemukakan sebagai berikut : 1) Pendidikan yang dilakukan harus berwawasan lingkungan, karena lingkungan banyak menyediakan alat bantu pembelajaran. 2) Alat bantu pembelajaran tidak harus dibeli dengan harga yang mahal, bendabenda lingkungan sekitar dapat diperoleh dengan mudah dan dikenal oleh siswa. 3) Hendaknya siswa diberi kesempatan sendiri untuk mencari alat bantu benda-benda kongkrit disekitar sekolah sesuai dengan keinginannya. 4) Karena alat bantu benda-benda kongkrit bersifat hanya sementara ajaklah siswa sekali waktu mengoperasionalkan penjumlahan dan pengurangan tenpa alat bantu. 5) Hendaknya siswa diberi kesempatan yang lebih banyak untuk tampil didepan kelas menyelesaikan soalsoal latihan, agar siswa terlatih dan timbul rasa percaya diri. 


\section{DAFTAR PUSTAKA}

Hopkins. D, 1993. A Teacher Guide To Classroom Research Buckingham : Open Unuversity Press.

Hamalik, 2002. Pendekatan Guru Kurikulum Berbasis Kompetensi. Bandung : Algensondo

Meier.2002 Active Learning. Boston; Allyn and
Mulyasa E, 2002. Kurikulum Berbasis

Kompetensi Bandung, Rosda Karya.

Purwodarminto, Prof.Dr. 1988. Kamus Bahasa

Indonesia. Jakarta Dep Dik Bud.

Wardhani,2004. PPPG. Jakarta : LIPI

Bacon. 